\title{
Imigrace a nový náboženský pluralismus. Srovnání situace v EU a USA
}

\author{
Immigration and the New Religious Pluralism. \\ An EU/US Comparison
}

\author{
José Casanova
}

ABSTRACT Text focuses on new non-European immigrants in the U.S. and EU and especially on the religions (primarily on Islam) they bring into their new destinations. The article compares a situation in the U.S. and in the EU, and the different traditions in dealing with the problem of religion's role in public life and accommodating religious "others" in Western Europe and in the U.S. While in Western Europe one can witness rising difficulties in the relations between Islam and the prevailing European secular discourse, the situation in the U.S. Is much better as the structure of American denominationalism is more ready to incorporate new religions to be part of the American civil religion, although this process is far from easy.

KEY WORDS Catholicism, denominationalism, Europe, immigration, Islam, religion, religious pluralism, secularism, U.S.

Během uplynulých čtyř desetiletí se společnosti ve Spojených státech a v západní Evropě staly hlavním cílem nových globálních migračních proudů. Ve Spojených státech změnil v roce 1965 nový imigrační zákon drakonické protiimigrační zákony z dvacátých let a obnovil dlouhou tradici imigrace. Nicméně narozdíl od prristěhovalců 19. století, kteří přicházeli převážně z Evropy, pocházeli noví přistěhovalci především z Latinské Ameriky a Asie a ve stále rostoucí míře ze všech koutů světa. V př́ípadě západní Evropy znamenalo toto nové přistěhovalectví radikální zvrat v dlouhé historii evropské emigrace do zbytku světa. ${ }^{1}$

V průběhu moderní éry byly západoevropské společnosti hlavním imigranty vysílajícím regionem na světě. V koloniálním období se evropští kolonisté a kolonizátoři, nájemní síly a trestanci, misionáři a podnikatelé usadili ve všech koutech světa. Odhaduje se, že v průběhu industrializace, od počátku 19. století do dvacátých let 20. století, emigrovalo do Nového světa a na jižní polokouli přibližně 85 milionů Evropanů, 60 \% z nich jen do samotných Spojených států. V posledních desetiletích se ale proud migrace otočil a západoevropské společnosti se staly centry globální imigrace.

Sociální studia. Fakulta sociálních studií Masarykovy univerzity, 1/2006. S. 29-53. ISSN 1214-813X.

Pracovní verze tohoto článku byla poprvé představena na Konferenci „Nový náboženský pluralismus a demokracie" na Georgetown University, 21.-22. dubna 2005 a nyní bude vydána v publikaci Thomas Banchoff(ed.) The New Religious Pluralism and Democracy (Oxford U. P.). Text publikujeme se svolením autora.

1 Charles Hirschman, Philip Kasinitz, Josh de Wind (eds.) The Handbook of International Migration: The American Experience, New York: Russell Sage, 1999; Leslie Page Moch, Moving Europeans. Migration in Western Europe since 1650, 2nd ed., Bloomington: Indiana University Press, 2003. 
Na počátku byly programy pro ,gastarbeitery“ v padesátých letech, které měly přilákat pracovní síly z méně vyspělých jihoevropských zemí (Itálie, Španělsko, Portugalsko, Jugoslávie, Řecko a Turecko). Dekolonizace pak do koloniálních metropolí (Francie, Velké Británie a Nizozemí) přivedla bývalé koloniální poddané ze severní a západní Afriky, jižní a jihovýchodní Asie a z Karibiku. Ekonomický rozklad, hladomory, politické konflikty, války a globální pašerácké sítě k tomu přidaly uprchlíky, uchazeče o azyl a ilegální imigranty z méně privilegovaných regionů, a to ještě dlouho po té, co v sedmdesátých letech skončil ekonomický boom následující po druhé světové válce a s ním také řízené programy pro migraci pracovní síly. Pád komunismu v roce 1989 otevřel brány novým imigrantům z východní Evropy a bývalého Sovětského svazu. Většina z původních gastarbeiterů pocházejících z chudších sousedních zemí se bud' vrátila domů, nebo se úspěšně integrovala v hostitelských zemích. V př́ípadě neevropských imigrantů se však politika dobrovolné repatriace ukázala být méně úspěšná a ,hostující pracovníci“ nejenže překročili dobu vymezenou pro jejich pozvání, ale usadili se v hostitelských zemích nastálo a přivedli si i své rodiny. V roce 2004 přijaly Španělsko a Itálie, které byly ještě před třemi desetiletími zeměmi vysílajícími do zbytku západní Evropy velké počty imigrantů, největší množství legálních přistěhovalců v Evropě, cca. 500000 a 400 000, zatímco země, které byly tradičními cíli legálních imigrantů (Německo, Francie a Velká Británie), byly schopny tyto počty zredukovat na 100000 a méně.

Ačkoliv je podíl zahraničních přistěhovalců na obyvatelstvu mnoha evropských zemí (Velká Británie, Francie, Nizozemí nebo západní Německo před sjednocením) přibližně na stejné úrovni, čili okolo 10 \%, stejně jako činí podíl v zahraničí narozených osob ve Spojených státech, je pro většinu evropských zemí stále problémem pohlížet na sebe jako na přistěhovalecké společnosti nebo pohlížet na osoby zahraničního původu (a dokonce i na již v daném státě narozenou druhou a třetí generaci jejich potomků) jako na spoluobčany, bez ohledu na jejich právní postavení. Spojené státy mají naopak sklon vnímat samy sebe jako paradigmatickou přistěhovaleckou společnost a rozdíl mezi v zemi narozeným občanem, naturalizovaným imigrantem, přistěhovalcem a přistěhovalcem nelegálním, i když je z právního hlediska jasný, není v běžném životě okamžitě patrný a často ani v mnoha sociálních kontextech důležitý. ${ }^{2}$

\section{Problém nové náboženské rozmanitosti v sekulární Evropě}

Jedním z nejvýznamnějších důsledků nového přistěhovalectví se stal dramatický nárůst náboženské rozmanitosti na obou stranách Atlantiku. Zatímco ve Spojených státech však přispěla náboženství nových imigrantů k již pulzujícímu americkému náboženskému pluralismu, v Evropě představují náboženství nových přistěhovalců výzvu místním modelům omezeného

Rainer Bauböck, Immigration and the Boundaries of Citizenship (Wien: Institut für Höhere Studien, 1991); Rainer Bauböck (ed.) From Aliens to Citizens: Redefining the Status of Immigrants in Europe (Aldershot: Ashgate, 1994); Rainer Bauböck, Agnes Heller, Aristide R. Zolberg (eds.) The Challenges of Diversity: Integration and Pluralism in Societies of Immigration (Aldershot: Ashgate, 1996); Rainer Bauböck a John Rundell (eds.) Blurred Boundaries: Migration, Ethnicity, Citizenship (Aldershot: Ashgate, 1998). 
náboženského pluralismu, jež se zdá být ještě významnější tváŕí v tvář evropskému trendu radikální sekularizace. Je pravda, že evropské společnosti se odlišují nejen od Spojených států, ale i samy mezi sebou ve způsobech, jakými se snaží pojmout a regulovat náboženství přistěhovalců, zejména islám. Evropské společnosti mají výrazně odlišné institucionální a právní struktury vztahující se k náboženským sdružením, velmi odlišnou politiku státního uznání, státní regulace a státní pomoci různým náboženským skupinám, jakož i odlišné normy týkající se toho, kdy a kde lze veřejně vyjadřovat něčí náboženskou víru a s ní spojené obřady. ${ }^{3}$

Evropské státy se při vypořádávání se s náboženstvími přistěhovalců snaží, podobně jako Spojené státy, o opakování svého konkrétního modelu oddělení církve od státu a modelů regulace, jež uplatňují u svých vlastních náboženských menšin. ${ }^{4}$ Francouzský etatistický sekulární model a politická kultura laïcité vyžadují striktní privatizaci náboženství a odstranění náboženství z jakéhokoliv veřejného fóra, zatímco současně vyvíjejí na náboženské skupiny tlak směřující $\mathrm{k}$ tomu, aby se organizovaly $\mathrm{v}$ jednotné, církvi podobné, institucionální struktuře, která by mohla být regulována a jež by plnila funkci partnera státu, což je pokračováním tradičního modelu konkordátu s katolickou církví. Na druhé straně Velká Británie, ač stále udržuje instituci anglikánské církve, rozvinula historicky daleko větší náboženský pluralismus a dnes umožňuje náboženským sdružením daleko větší svobodu; tato sdružení jednají př́mo s místními orgány a se školními radami a vyvíjejí tlak na změnu ve výuce náboženství, stravování atd., bez nutnosti navazování kontaktů nebo vznášení požadavků vůči ústřední vládě. Německo, následující multi-institucionální model, se pokusilo o vytvoření kvazi oficiálních islámských institucí - občas souběžně se snahou tureckého státu o řízení turecké diaspory. Nicméně vnitřní rozpory mezi přistěhovalci $\mathrm{z}$ Turecka a veřejná proklamace a mobilizace soupeřících identit (sekulární muslimové, Alávité, Kurdové) zmařily v německém demokratickém prostředí jakékoliv pokusy o institucionalizaci shora. Holandsko se až donedávna, v souladu se svým tradičním modelem tzv. „sloupư“, snažilo o vytvoření státem kontrolovaného, ale samosprávného a samostatného muslimského pilíre. Nedávno si nicméně i takto liberální Holandsko celou věc rozmyslelo a zdá se, že je připraveno přijmout restriktivnější legislativu, která stanoví jasné mantinely typům ne-evropských, ne-moderních norem a zvyků, které je ochotné tolerovat.

Podíváme-li se na západní Evropu jako na celek, vidíme ve srovnání se situací ve Spojených státech dvě zásadní odlišnosti. Za prvé, přinejmenším v kontinentální Evropě, jsou přistěhovalectví a islám téměř synonymy. S výjimkou Velké Británie, kde lze mezi přistěhovalci z bývalých britských kolonií zaznamenat větší rozmanitost, byla až donedávna většina přistěhovalců ve většině evropských zemích muslimského vyznání. Navíc až na nepatrný a symbolický výskyt malých skupin evropských konvertitů $\mathrm{k}$ islámu tvoří drtivou většinu západoevropských muslimů přistěhovalci. Tato identifikace imigrace a islámu je ještě zjev-

S. Ferrari a A. Bradney (eds.) Islam and European Legal Systems, Aldershot: Ashgate, 2000.

John Madeley a Zsolt Enyedi (eds.) Church and State in Contemporary Europe, London: Frank Cass, 2003; Ted Jelen a Clyde Wilcox (eds.) Religion and Politics in Comparative Perspective: The One, the Few and the Many, New York: Cambridge University Press, 2002; W.A.R. Shadid a P.S. Koningsveld (eds.) Religious Freedom and the Position of Islam in Western Europe, Kampen: Kok Pharos, 1995. 
nější v př́ípadech, kdy většina muslimských přistěhovalců pochází z jednoho regionu, například Turecka v př́padě Německa, či země Maghribu v případě Francie. To má za následek superponování různých dimenzí „odlišnosti“ (jinakosti), jež zhoršuje problémy vymezování se, přijetí a inkorporace. Přistěhovalecké, náboženské, rasové a sociálně-ekonomicky znevýhodněné ,jiné“ má tendenci splývat. ${ }^{5}$

Naproti tomu ve Spojených státech tvoří muslimové v nejlepším prrípadě $10 \%$ všech nových přistěhovalců a toto číslo se bude pravděpodobně snižovat, pokud budou pokračovat přísná omezení pro arabskou a muslimskou imigraci zavedená po 11. záŕí. Protože Statistický úřad Spojených států, Immigration and Naturalization Service a další vládní agentury nesmějí shromažd'ovat údaje týkající se náboženství, neexistují žádná spolehlivá data o počtu muslimů ve Spojených státech. Stávající, ale často jednostranně zaměřené odhady se pohybují v širokém rozmezí od 2,8 do 8 milionů. Lze se odůvodněně domnívat, že skutečné číslo se nachází někde uprostřed, mezi 4 až 6 miliony. O něco spolehlivější je odhad, že zhruba 30 až 42 procent všech muslimů ve Spojených státech tvoří afroameričtí konvertité k islámu, což problematizuje označení islámu za cizí, ne-americké náboženství. Komunity muslimských přistěhovalců žijící ve Spojených státech se navíc neobyčejně liší z hlediska geografického původu, z hlediska př́ślušné islámské tradice a z hlediska sociálně-ekonomických rysů. $\mathrm{V}$ důsledku toho je dynamika interakcí s dalšími muslimskými imigranty, s černošskými muslimy, s nemuslimskými přistěhovalci pocházejícími ze stejného regionu a s jejich nejbližšími americkými hostiteli - v závislosti na socio-ekonomických rysech a modelu osídlení - komplexnější a rozmanitější než cokoliv, s čím se můžeme setkat v Evropě. ${ }^{6}$

Druhá odlišnost souvisí s rolí, jež náboženství a skupinové náboženské identity hrají ve veřejném životě a při organizaci občanské společnosti. Bez ohledu na vnitřní odlišnosti jsou západoevropské společnosti hluboce sekulární, formované hegemonním vědomím sekularismu. ${ }^{7}$ Postupná, i když nestejnoměrná sekularizace Evropy je nepopiratelnou sociální skutečností. ${ }^{8}$ Je pravdou, že úroveň zbožnosti se např́ič Evropou výrazně liší. Východní Německo je podle všech kritérií daleko nejméně nábožensky založenou zemí Evropy, s odstupem následováno Českou republikou a skandinávskými zeměmi. Na druhém konci stupnice jsou Irsko a Polsko, daleko nejvíce nábožensky založené země Evropy, jež jsou srovna-

Jocelyne Cesari, When Islam and Democracy Meet: Muslims in Europe and in the United States, New York: Palgrave Macmillan, 2004; W.A.R. Shadid a P.S. Koningsveld (eds.) Muslims in the Margin: Political Responses to the Presence of Islam in Western Europe, Kampen: Kok Pharos, 1996; Steve Vertovec a Ceri Peach (eds.), Islam in Europe: The Politics of Religion and Community, Basingstoke: McMillan, 1997; J. Rath, R. Penninx, K. Groenendijk, a A. Meyer, Western Europe and Its Islam. The Social Reaction to the Institutionalization of „New Religion “ in the Netherlands, Belgium and the United Kingdom, Leiden: Brill, 2001; Brigitte Maréchal, Stefano Allievi, Felice Dassetto a Jorgen Nielsen (eds.), Muslims in the Enlarged Europe, Leiden: Brill, 2003.

$6 \quad$ Karen Isaksen Leonard, Muslims in the United States: The State of Research, New York: Russell Sage, 2003; Yvonne Yazbeck Haddad (ed.), Muslims in the West: From Sojourners to Citizens, New York: Oxford University Press, 2002; Yvonne Yazbeck Haddad a John L. Esposito (eds.), Muslims on the Americanization Path?, Atlanta, GA.: Scholars Press, 1998; Yvonne Yazbeck Haddad a Jane Idleman Smith, Muslim Minorities in the West: Visible and Invisible, Walnut Creek, CA: AltaMira Press, 2002. 
telné se Spojenými státy. Obecně lze konstatovat, že s výjimkou Francie a České republiky jsou katolické země více nábožensky založené než země protestantské nebo smíšené (západní Německo, Nizozemí), byt' Švýcarsko (smíšená a tradičně segmentovaná země srovnatelná s Holandskem) zaujímá na evropské žebřičku religióznosti vysoké místo a blíží se katolickému Rakousku a Španělsku, které obě zaznamenávají drastický pokles religiozity.

$\mathrm{V}$ každém př́ípadě se $\mathrm{v}$ Evropě od šedesátých let přestala rostoucí většina společnosti podílet na tradičních náboženských obřadech, přinejmenším na jejich pravidelném dodržování, i když si udržela poměrně vysokou úroveň soukromého náboženského vědomí. $Z$ tohoto hlediska lze možná hovořit o odcírkevnění evropské populace a o náboženské individualizaci, spíše než o sekularizaci. Grace Davie $(1994,2000)$ charakterizoval tuto obecnou evropskou situaci jako „víru bez přináležitosti“ (k nějaké skupině/církvi - pozn. překl.). ${ }^{9}$ Velké množství Evropanů i v těch nejvíce sekularizovaných zemích se však současně označuje za „křestany“, čímž jsme upozorňováni na implicitní, rozptýlenou a zanořenou křest’anskou kulturní identitu. V tomto smyslu má pravdu také Danièle Hervieu-Léger, když nabízí obrácenou charakteristiku evropské situace jako „přináležitost bez víry“. ${ }^{10}$ Od Francie po Švédsko a od Anglie po Skotsko jsou historické církve (katolická, luteránská, anglikánská nebo kalvinistická), byt' zbavené aktivního členství, stále funkční a stále nahližené jako veřejní nositelé národního náboženství. Z tohoto hlediska jsou „sekulárni““ a „křest’anská“ kulturní identita u většiny Evropanů propletené komplexním a jen zřídka verbalizovaným způsobem.

Sociologicky nejzajímavější otázkou pak opravdu není skutečnost postupného oslabování postavení náboženství v evropské populaci od 50. let 20. století, ale skutečnost, že je toto oslabování interpretováno optikou sekulárního paradigmatu, a je proto doprovázeno „sekularistickým“" sebepojetím, které toto oslabování interpretuje jako „normální“ a „pokrokové“, tzn. jako kvazi-normativní důsledek bytí „moderním“ a „osvíceným“ Evropanem. Musíme se vážně zabývat tezí, že v okamžiku, kdy široké vrstvy populace v západoevropských společnostech (včetně křest’anských církví) prrijaly základní premisu teorie sekularizace: totiž, že sekularizace je teleologickým procesem moderní sociální změny; že čím modernější společnost, tím sekulárnější je; že „sekulárnost“ je znamením doby; stala se sekularizace $v$ Evropě sebenaplňujícím se proroctvím. Pokud je tato teze správná, pak lze sekularizaci západoevropských společností lépe vysvětlit jako triumf sekulárního vědění než z hlediska strukturálních procesů sociálně-ekonomického vývoje jako je urbanizace, vzdělání, racionalizace atd. Vzájemné odlišnosti přítomné v rámci Evropy mohou být navíc

7 Následující část je založena na argumentaci, která je obšírně rozvedena v José Casanova, „Religion, Secular Identities and European Integration, “ in Peter Katzenstein a Timothy Byrnes (eds.), Religion and European Integration, Cambridge: Cambridge University Press, 2006.

8 David Martin, A General Theory of Secularization, New York: Harper \& Row, 1978; Andrew M. Greeley, Religion in Europe at the End of the Second Millennium: A Sociological Profile, New Brunswick, N.J.: Transaction Books, 2003.

$9 \quad$ Grace Davie, Religion in Britain Since 1945: Believing Without Belonging, Oxford: Blackwell, 1994 a Religion in Modern Europe: A Memory Mutates, Oxford: Oxford University Press, 2000.

10 Daniéle Hervieu-Léger, „Religion und Sozialer Zusammenhalt.“ Transit. Europäische Review, 26, Sommer, 2004. 
lépe vysvětleny $\mathrm{z}$ hlediska historických modelů vztahů církev-stát a církev-národ a stejně tak z hlediska odlišných průběhů sekularizace v rámci různých větví křest’anství, než z hlediska úrovní modernizace.

Je to právě tato „sekulární“ identita, sdílená jak evropskou elitou, tak obyčejnými lidmi, která paradoxně proměňuje „náboženstvi““ a jen sotva zanořenou evropskou křest’anskou identitu v ožehavý a do rozpaků přivádějící problém, objevující se tehdy, když dojde na vytyčování vnějších geografických hranic a na definování vnitřní kulturní identity Evropské unie v procesu jejího vytváření. Ostré debaty ohledně možného přijetí muslimského Turecka do Evropské unie překrývají debaty o selhání integrace druhých a třetích generací muslimských přistěhovalců v Evropě, přičemž ale obojí přispívá k vidině „islámu“ jako „toho cizího/protikladného“ ve vztahu k modernímu liberálnímu sekulárnímu Západu. Debaty o výslovném odkazu na Boha a křest'anské dědictví v preambuli nové evropské ústavy navíc ukázaly, že ani ne tak Turecko, ale právě Evropa je „rozpolcenou zemí“, která je hluboce rozdělena $\mathrm{v}$ otázce své kulturní identity a není schopna odpovědět na otázku, zda by měla být evropská jednota, a tedy i její vnější a vnitřní hranice, definována společným dědictvím křest’anství a západní civilizace, nebo jejími moderními sekulárními hodnotami liberalismu, univerzálních lidských práv, politickou demokracií a tolerantním a inkluzivním multikulturalismem. Evropské liberálně sekulární elity nemohou samozřejmě veřejně sdílet papežskou definici evropské civilizace jako ve své podstatě civilizace křest’anské. Nemohou také verbalizovat nevyslovené „kulturní“ požadavky, které vytvářejí z integrace Turecka do Evropy tak složitý problém. Př́źrak milionů tureckých občanů, kteří se již nacházejí v Evropě, avšak z Evropy nepocházejí, přičemž mnozí z nich jsou již druhou generací přistěhovalců, sevřenou mezi starou vlastí, kterou opustili, a svými evropskými hostiteli, kteří nejsou schopni nebo ochotni je plně asimilovat, činí tento problém ještě viditelnějším. „Gastarbeitři““ mohou být úspěšně inkorporováni ekonomicky. Mohou dokonce získat volební právo, přinejmenším na místní úrovni, a ukázat se jako vzoroví, nebo alespoň obyčejní občané. Mohou ale překonat nepsaná pravidla evropského kulturního členství, nebo musejí zůstat „cizinci“? Může Evropská unie nabídnout nové podmínky pro ten druh multikulturalismu, který je pro její jednotlivé národní společnosti tak těžko přijatelný? Debaty, jež v současné době v Evropě probíhají, poukazují na zásadní napětí mezi kosmopolitním sekularismem a tím druhem multikulturalismu, který by mohl způsobit veřejné uznání mravů, zvyků a životního stylu muslimů a dalších přistěhovaleckých náboženských komunit. ${ }^{11}$

Všechny evropské společnosti, jako liberálně demokratická zřízení, respektují a ústavně chrání soukromé praktikování náboženství, včetně islámu, jako individuální lidské právo. Veřejné a kolektivní vyznávání islámu jako přistěhovaleckého náboženství je ale věcí, kterou většina evropských společností toleruje jen obtížně, a to právě z toho důvodu, že islám je vnímán jako v postatě „ne-evropské“ náboženství. Odůvodnění uváděná na podporu pojetí islámu jako „ne-evropského“ se např́íc Evropou a mezi sociálními a politickými skupinami značně liší. Pro protipřistěhovaleckou, xenofobní, nacionalistickou pravici, představovanou

11 Tariq Modood, Multicultural Politics. Racism, Ethnicity, and Muslims in Britain, Minneapolis: University of Minnesota Press, 2005; Tariq Modood a Pnina Werbner (eds.), The Politics of Multiculturalism in the New Europe: Racism, Identity, and Community, London: Zed Books, 1997. 
Le Penem ve Francii a Jörgem Haiderem v Rakousku, je vzkaz jasný. Islám je nevítaný a neasimilovatelný jednoduše proto, protože je ,cizím“ přistěhovaleckým náboženstvím. Takový nativistický a obvykle rasistický postoj lze zřetelně odlišit od konzervativního „katolického“ postoje, který paradigmaticky vyjádřil boloňský kardinál, když prohlásil, že Itálie by měla vítat prristěhovalce všech ras a ze všech světových regionů, ale měla by si vybírat zvláště přistěhovalce katolické, aby byla uchována katolická identita země. Křest'ansko demokratické strany se ve skutečnosti staly kulturními obránci úzce, nativisticky a teritoriálně definované evropské křest’anské identity v době, kdy se tisícileté ztotožňování křest’anství s evropskou civilizací chýlí ke konci díky duálnímu procesu reprezentovanému pokročilou sekularizací v postkřest’anské Evropě a vzrůstající globalizací deteritorializovaného a střed postrádajícího ne-evropského křest'anství.

Liberálně sekulární Evropané mají sklon nahlížet na taková bezostyšná vyjádření rasistické bigotnosti a náboženské netolerance, vycházející od nacionalistických a náboženských konzervativců, s nedůvěrou. Když jde však o islám, dojde i u sekulárních Evropanů k odhalení mezí a předsudků jejich moderní sekulární tolerance. Je nepravděpodobné, že bychom mezi liberálními politiky a sekulárními intelektuály zaslechli explicitně xenofobií nebo protináboženská prohlášení. Politicky korektní formulace znějí ve stylu „vítáme jednoho každého a všechny přistěhovalce bez ohledu na jejich rasu či náboženské vyznání, pokud jsou ochotní respektovat a akceptovat naše moderní liberálně sekulární evropské normy“. Konkrétní znění těchto norem se stát od státu liší. Spory ohledně muslimských šátků v mnoha evropských společnostech a drtivá podpora zákona zakazujícího nošení muslimských šátků a dalších ostentativně náboženských symbolů ve státních školách, přičemž francouzskými občany - a zdá se, že včetně většiny francouzských muslimů - jsou tyto symboly označovány za „ohrožení národní soudržnosti“", může být extrémním příkladem neliberálního sekularismu. ${ }^{12}$ Ve skutečnosti lze nalézt podobný trend restriktivní legislativy namířené proti přistěhovalým muslimům i v liberálním Holandsku, právě z důvodu ochrany jeho liberální tolerantní tradice proti hrozbě neliberálních, fundamentalistických, patriarchálních zvyků reprodukovaných a přenášených muslimskými přistěhovalci na mladší generaci.

Je př́značné, že francouzský premiér Jean-Pierre Raffarin poukázal ve své řeči obhajující v Národním shromáždění zákaz ostentativních náboženských symbolů ve státních školách jedním dechem na Francii jako na „starou křest’anskou zemi“ i na nedotknutelnou zásadu lä̈cité a vyzval islám $\mathrm{k}$ adaptování se na princip sekularismu, jako to udělala i jiná náboženství ve Francii. „Pro posledně příchozího, mám zde na mysli islám, je sekularismus šancí, šancí být náboženstvím Francie““. ${ }^{13}$ Zákaz islámského závoje a jiných náboženských symbolů na státních školách je ospravedlnitelný, protože ,nabírají politický význam“, zatímco podle sekulárního

12 John Bowen, „Muslims and Citizens, France's Headscarf Controversy,“ Boston Review, February/ March 2004; Talal Asad, „Trying to Understand French Secularism, “ in Hent de Vries (ed.), Political Theologies, New York: Fordham University Press, 2006; N. Weibel, Par Delŕ le Voile: Femmes d'Islam en Europe, Brussels: Complexe, 2000; F. Gaspard a F. Khosrokhavar, Le Foulard et la République, Paris: La Découverte, 1995.

13 Elaine Sciolino, ,Debate Begins in France on Religion in the Schools, “ The New York Times, February 4, 2004. 
principu privatizace náboženství „,náboženství nesmí být politickým projektem“. Čas ukáže, zda budou mít tyto restriktivní zákony zamýšlený účinek a zda zastaví šíření „,radikálního islámu“, nebo zda přinesou naopak další radikalizaci již nyní odcizené a nepřizpůsobivé přistěhovalecké komunity.

Kladná hodnocení, která lze na podporu takovýchto neliberálních omezení svobodného vyznávání náboženství zaslechnout mezi liberály, jsou obvykle formulována z hlediska žádoucí nucené emancipace mladých dívek od diskriminace na základě pohlaví a od patriarchální kontroly, jež by měla v př́padě nutnosti probíhat i proti jejich vưli. Na tomto diskurzu postavil svou volebně úspěšnou protipřistěhovaleckou platformu v liberálním Holandsku zavražděný holandský politik Pim Fortuyn, kampaň, která nyní nese ovoce v podobě nových restriktivních zákonů a dalšího násilí. Zatímco o konzervativních nábožensky založených lidech se přepokládá, že budou tolerovat chování, které mohou považovat za morálně odpudivé (jako např. homosexualitu), liberálně sekulární Evropané prohlašují, že evropské společnosti by neměly tolerovat náboženské chování nebo kulturní zvyky, které jsou morálně odpudivé do té míry, do jaké jsou v rozporu s moderními liberálními a sekulárními evropskými normami. To, co činí netolerantní tyranii sekulárně liberální většiny v principu ospravedlnitelnou, není jen demokratický princip většinové vlády, ale spíše sekulární teleologický předpoklad zabudovaný v teoriích modernizace, podle nějž je jeden soubor norem reakcionářský, fundamentalistický a protimoderní, zatímco druhý je pokrokový, liberální a moderní.

Protipřistěhovalecký xenofobní nativismus, sekularistické protináboženské předsudky, liberálně-feministická kritika muslimského patriarchálního fundamentalismu a strach z islamistických teroristických sítí jsou napříč Evropou směšovány do jednotného protimuslimského diskurzu, který v podstatě znemožňuje vzájemný kompromis mezi skupinami přistěhovalců a hostitelskými společnostmi, který je nezbytný pro úspěšné začlenění imigrantů. ${ }^{14}$ Podobnosti s protestantským republikánským protikatolickým nativismem v Americe v polovině 19. století jsou skutečně zarážející. Dnešní totalizující diskurz o islámu jako v podstatě protimoderním, fundamentalistickém, neliberálním a nedemokratickém náboženství a kultuře připomínají diskurz 19 . stoletní ve vztahu ke katolicismu. ${ }^{15}$

Evropské společnosti tolerují a respektují individuální náboženskou svobodu. Nicméně v důsledku tlaku na privatizaci náboženství, která se v evropských společnostech stala samozřejmým rysem sebedefinice moderní sekulární společnosti, mají tyto společnosti mnohem větší obtíže s uznáním určité legitimní role náboženství, již hraje ve veřejném životě a při organizování a mobilizaci kolektivních skupinových identit. Muslimské organizované kolektivní identity a jejich veřejné prezentování se staly zdrojem znepokojení nejen kvůli své náboženské jinakosti jako př́klady ne-křest’anského a ne-evropského náboženství, ale ještě více kvůli jejich samot-

14 Proslulé vyjádření islamofobie lze nalézt např. v Oriana Fallaci, The Rage and the Pride, New York: Rizzoli, 2002. Srov. Jocelyne Cesari, L'Islam à l'Épreuve de l'Occident, Paris: La Découverte, 2004; Runnymede Trust, Islamophobia: a Challenge for Us All, London: Runnymede Trust, 1997; B. Said, a Fundamental Fear: Eurocentrism and the Emergence of Islamism, London: Zed Books, 1997; V. Geisser, La Nouvelle Islamophobie, Parisl La Découverte, 2003.

15 José Casanova, „Civil Society and Religion: Retrospective Reflections on Catholicism and Prospective Reflections on Islam“, Social Research 68, 4 Winter, 2001. 
né religióznosti jako protikladu k evropské sekulárnosti. V tomto kontextu se stává pokušení ke ztotožnění islámu a fundamentalismu ještě zjevnější. Islám se z definice stává tím druhým, opakem k západní sekulární modernitě, což je ztotožnění, které je superimponováno na starší obraz islámu jako protikladu evropského křest’anstva. Problémy spojené se začleněním muslimských imigrantů se vědomě či nevědomě spojily se zdánlivě př́ibuzným a otravným problémem definice role náboženství ve veřejné sféře, o kterém se evropské společnosti domnívaly, že ho již vyřešily podle liberálně sekulární normy o privatizaci náboženství. ${ }^{16}$

\section{Přistěhovalecká náboženství a expanze amerického denominacionalismu ${ }^{17}$}

Strukturální podmínky, se kterými se přistěhovalci setkávají ve Spojených státech, se podstatně liší. A to nejen proto, že Američané jsou zjevně více nábožensky založení než Evropané a existuje tedy určitý tlak na přizpůsobení se americkým náboženským normám. Ještě významnější je to, že dnes, stejně jako v minulosti, hrají veřejné náboženské denominační identity významnou roli v procesu začleňování nových přistěhovalců. Narážíme tak zde na paradox, který stále znovu a znovu udivuje badatele zkoumající přistěhovalecké komunity a který lze vyjádřit slovy Raymonda Williamse, že ,přistěhovalci jsou podle všeho mnohem víc nábožensky orientovaní než byli před tím, než opustili své domovy“. ${ }^{18}$

Je důležité si uvědomit, že religiozita přistěhovalců není pouze zbytkem tradic, starým světem, který je v průběhu přizpůsobování se novým podmínkám odsouzen $\mathrm{k}$ zániku, ale spíše adaptivní odpovědí na nový svět. Zdá se mi nicméně nepřesvědčivé vysvětlení Timothy

José Casanova, Public Religions in the Modern World, Chicago: University of Chicago Press, 1994.

Následující pasáž podstatným způsobem čerpá ze stale nepublikovaných výsledků výzkumného projektu RIINY, „Religion and Immigrant Incorporation in New York,“ prováděného pod vedením José Casanovy a Aristide Zolberga v International Center for Migration, Ethnicity, and Citizenship na New School for Social Research, New York. RIINY (1999-2002) byl jedním ze sedmi projektů „Vstupních měst“ financovaných společností Pew Charitable Trusts.

18 Timothy L. Smith, „Religion and Ethnicity in America“ American Historical Review 83, 1978. Tvrzení, že se přistěhovalci stávají více nábožensky založenými tím, čím více se amerikanizují, bylo hlavním bodem myšlenky Willa Herberga v jeho klasické studii Protestant-Catholic-Jew, Garden City, N.Y.: Doubleday, 1960. Stejné tvrzení bylo opakováno i v nejnovějších studiích o náboženství přistěhovalců v Americe. Srov. např́klad R. Stephen Warner a Judith G. Wittner (eds.), Gatherings in Diaspora: Religious Communities and the New Immigration, Philadelphia: Temple University Press, 1998; Helen Rose Ebaugh a Janet Saltzman Chafetz (eds.), Religion and the New Immigrants, Walnut Creek, CA: AltaMira Press, 2000; Ho-Youn Kwon, Kwang Chun Kim a R. Stephen Warner (eds.), Korean Americans and Their Religions, University Park, PA.: Pennsylvania State University Press, 2001; Fenggang Yang, Chinese Christians in America, University Park, PA.: Pennsylvania State University Press, 1999; Raymond Brady Williams, Religion of Immigrants from India and Pakistan: New Threads in the American Tapestry, New York: Cambridge University Press, 1988; Prema Kurien, ,„We Are Better Hindus Here' Religion and Ethnicity Among Indian Americans“ v Jung Ha Kim a Pyong Gap Min (eds.), Building Faith Communities: Asian Immigrants and Religions, Walnut Creek, CA: AltaMira Press, 2002. 
Smitha, že je to právě sama přistěhovalecká zkušenost, která způsobuje tuto náboženskou odpověd’, protože sama imigrace je „teologizující“ zkušeností, nebot' vykořenění z tradičního běhu života, nejistota cesty a anomický prožitek $\mathrm{z}$ bytí cizincem $\mathrm{v}$ nové zemi vyvolávají tuto náboženskou odpověd’.

Velmi často se setkáváme $\mathrm{s}$ tím, že $\mathrm{z}$ fenomenologického hlediska se mnoho přistěhovaleckým skupin při pokusech o vyjádření a verbalizaci přistěhovalecké zkušenosti uchyluje $\mathrm{k}$ náboženskému jazyku a navazuje na dostupné diskurzivní archetypy převzaté z různých náboženských tradic, přičemž svou zkušenost interpretuje skrze pout' (křest'ané a hinduisté) nebo jako exodus do země zaslíbené (puritáni, židé a černoši) anebo jako novou hidžru (muslimové). Problémy nastávají, když se toto konkrétní fenomenologické vnímání přemění v neo-durkheimovské všeobecné vysvětlení, jež ho pojímá jako reaktivní okamžité odpovědi na kulturní tlaky a anomickou dezintegraci spojenou s vykořeňující zkušeností imigrace. Takové všeobecné vysvětlení není uspokojivé, protože u současných přistěhovaleckých skupin př́tomných v Americe můžeme nalézt nepřebernou škálu náboženských projevi̊, od korejských Američanů, kteří jsou pravděpodobně více nábožensky založení než kterákoliv jiná přistěhovalecká nebo domácí etnická skupina $\mathrm{v}$ Americe, $\mathrm{k}$ židům z bývalého SSSR, kteří jsou zde stejně málo nábožensky založení, jako byli ve své staré vlasti. Důležitější však je, že se nejedná o príijatelné a věrohodné všeobecné vysvětlení, protože není potvrzeno podobnou zkušeností z jiných přistěhovaleckých společností - at' už současných, nebo minulých. ${ }^{19}$

Není to tedy obecný kontext přistěhovalectví, ale konkrétní kontext přistěhovalectví do Ameriky a strukturální a institucionální kontext americké společnosti, co vyvolává konkrétní náboženskou reakci. Teze Willa Herberga (1965, 27 a n.) vztahující se ke starému evropskému přistěhovalci, podle níž ,se od něj nejen očekávalo, že si uchová své staré náboženství, i když nikdo neočekával, že si uchová svůj starý jazyk a národnost, že avšak situace v Americe byla taková, že právě prostřednictvím náboženství nalezl on, nebo spíše jeho děti a vnukové, identifikovatelné místo v americkém životě“, stále platí i o nových přistěhovalcích. ${ }^{20}$ Tato teze implikuje nejen to, že přistěhovalci mají sklon být zbožní kvůli určitému sociálnímu tlaku na přizpůsobení se americkým náboženským normám, ale také to, že kolektivní náboženské identity byly jedním z hlavních způsobů strukturování vnitřního společenského pluralismu $\mathrm{v}$ americké historii.

Jelikož mají Američané pravděpodobně sklon být obecně zbožnější, než většina lidí v jiných moderních společnostech, budou mít přistěhovalci v Americe tendenci přizpůsobit se americké normě. „Jsi-li v Ř́mě, chovej se jako Ř́man.“ O tlaku na přizpůsobení se americkým standardům zbožnosti lze sotva pochybovat. Zeptejte se kteréhokoliv kandidáta na politickou funkci, zda si může dovolit přiznat, že je „bez vyznání“. Tím, co je zde důležité, je

Venkovští imigranti z italského jihu na přelomu 20. století měli, když se přesouvali do městských průmyslových center v severní Itálii nebo do katolické Argentiny, například sklon k přijímání antiklerikálních socialistických a anarchistických identit, zatímco když migrovali do průmyslových center Spojených států, měli sklon stávat se „lepšími“ praktikujícími katolíky. V současnosti lze provést obdobné srovnání mezi hinduistickou imigrací v Londýně a v New Yorku nebo mezi frankofonními západoafrickými muslimy v Paříži a v New Yorku.

Herberg, Protestant-Catholic-Jew, s. 27-28. 
„definice situace“. Jelikož se Američané definují jako zbožní lidé, myslí a jednají v souladu $\mathrm{s}$ touto sebedefinicí. Ještě více zaráží skutečnost, že mají sklon lhát tazatelům při výzkumech a přehánět své návštěvy kostela a zveličovat hloubku a vážnost své náboženské víry. ${ }^{21}$ Tato tendence Američanů k přehánění vlastní zbožnosti je v př́mém kontrastu s opačnou tendencí Evropanů ke zlehčování a podceňování jejich vlastní přetrvávající zbožnosti a tyto sklony, které jsou zjevné mezi obyčejnými lidmi stejně jako mezi vzdělanými lidmi na obou stranách Atlantiku, jsou samy součástí velmi rozdílných a závažných definicí situace na obou místech. Je zjevné, že Američané si myslí, že se od nich čeká, že budou zbožní, zatímco Evropané si myslí, že mají deklarovat svou sekulárnost. To by alespoň částečně vysvětlovalo to, proč mají stejné skupiny přistěhovalců sklon být zbožnější a prezentovat svoji náboženskou identitu otevřeněji ve Spojených státech než ve většině evropských zemích.

$\mathrm{Z}$ mého hlediska jsou ale důležitější strukturální podmínky utvářející americký náboženský pluralismus než rozptýlený společenský tlak na přizpůsobení se americkým náboženským normám. Skutečnost, že náboženství, náboženské instituce a náboženské identity hrály ústřední roli v procesu začleňování starých evropských přistěhovalců, byla bohatě zdokumentována. V konkrétním případě přistěhovalectví do Ameriky měly náboženské identity sklon spíše k posilování své význačnosti, než k jejímu potlačování, jak by se dalo předpokládat podle obecných teorií modernizace a sekularizace. Herbergova myšlenka implikuje, že kolektivní náboženské identity představovaly primární způsob strukturování vnitřního společenského pluralismu v americké historii, čehož příčinou měla být skutečnost, že „struktura americké společnosti postulovala téměř od samého počátku rozmanitost a reálnou rovnost náboženských sdružení“. 22

Konkrétní model separace církve a státu, který byl kodifikován ve dvou odstavcích prvního dodatku, „svobodné vyznávání náboženství“ a „,neustavení žádného vedení“ (jednoho náboženství - pozn. překl.), posloužil ke strukturování této rozmanitosti a skutečné rovnosti (denominací - pozn. překl.). Po získání nezávislosti bylo zavedení jedné konkrétní církve na federální úrovni vyloučeno pravděpodobně územním rozložením a relativně stejnou silou tří koloniálních církví: kongregační, presbyteriánské a anglikánské. Nicméně výsledkem mohlo být ustavení trojitého vedení nebo zavedení všeobecného křest'anského (rozuměj protestantského) náboženství jako oficiálního, nebylo-li by ovšem aktivní koalice Jeffersona, Madisona a nonkonformních baptistů ve Virginii.

Formulace obsažená v americké ústavě zpochybnila názor, který byl přijímán jako samozřejmost jak lidmi př́slušejícími k nějakému náboženství, tak sekularisty (deisty), že totiž stát nebo politické společenství občanů potřebuje náboženství, církevní nebo občanské, jako základ pro svoji normativní integraci a že navíc patří k pravomocím suveréna regulovat náboženskou sféru. První dodatek nejenže vztyčil „oddělující zed"“ chránící stát vůči náboženství (,žádné vedení) a náboženství vůči státu (svobodné praktikování), ale v podstatě zavedl princip rozlišování mezi politickým společenství občanů a všemi náboženskými komunitami bez výjimky. Nakonec se všechna náboženství v Americe, církve stejně jako sekty, bez ohledu na

21 Kirk Hadaway, Penny Long Marler a Mark Chaves, „What the Polls Don't Show: a Closer Look at U.S. Church Attendance,“ American Sociological Review, 58, 1993.

22

Herberg, s. 27. 
jejich původ, doktríny a duchovní identitu, stanou „denominacemi“, které jsou si podle ústavy formálně rovné a soutěží na relativně volném, pluralistickém a dobrovolném trhu náboženství. Jako organizační forma a pravidlo náboženského systému představuje denominacionalismus velký americký náboženský vynález. ${ }^{23}$

Rozmanitost a reálná rovnost byly původně institucionalizovány jako vnitrokonfesijní pluralismus uvnitř amerického protestantismu. Amerika byla definována jako „křest’anský“ stát a křest’anský znamenalo výhradně ,protestantský“. Nicméně nakonec, po dlouhotrvajícím výbuchu protestantského nativismu namíreného primárně vůči katolickým přistěhovalcům, tento model umožnil začlenění náboženských ,jiných“, katolíků a židů, do systému amerického náboženského pluralismu. ${ }^{24}$ Došlo k procesu dvojího narovnání, kdy se katolictví a judaismus staly americkými náboženstvími, a současně došlo i $\mathrm{k}$ transformaci amerického náboženství a státu. Amerika se stala ,židovsko-křest’anskou“ a protestanti, katolíci a židé se stali třemi denominacemi amerického občanského náboženství. Je to právě tento konečný výsledek, asimilace evropských katolických a židovských přistěhovalců do amerického mainstreamu, který oslavuje Herbergova kniha. ${ }^{25}$ A stojí za to připomenout, že je to tentýž sebeuspokojivý kontext inaugurační řeči prvního katolického prezidenta, které sloužily jako podklad Bellahovy teze pojednávající o občanském náboženství v Americe o jedno desetiletí později. ${ }^{26}$

Herbergova teze o americkém etnicko-náboženském pluralismu má vážné nedostatky. Nejflagrantnějším z nich je skutečnost, že Herberg naprosto ignoruje rasové problémy a zkoumá pouze proces začleňování protestantských-katolických-židovských evropských přistěhovalců, zatímco zcela mlčí o ne-evropských přistěhovalcích. Základním problémem není to, že Herberg ignoruje ostatní menšiny ne-evropských přistěhovalců a jejich ne-židovsko-křest’anská náboženství, jako jsou japonští buddhisté nebo čínští taoisté či arabští muslimové,

23 Sydney E. Mead, „Denominationalism: The Shape of Protestantism in America,“ v The Lively Experiment: The Shaping of Christianity in America, New York: Harper \& Row, 1976; Andrew M. Greeley, The Denominational Society; a Sociological Approach to Religion in America, Glenview, Ill.: Scott, Foresman, 1972. V západní Evropě naopak zůstal zachován model jedné jediné církve, která tvrdí, že obsahuje celý národ nebo model dvou (katolické a protestantské) soupeřících, ale teritoriálně ukotvených národních církví společně s neurčitým počtem náboženských menšin, které přijímají vůči národní (státní) církvi /církvím strukturální pozici sekt. Ukrajina je možná jedinou evropskou společností, která připomíná denominační model. Srov. José Casanova, „Between Nation and Civil Society: Ethno-Linguistic and Religious Pluralism in Ukraine, "v Robert Heffner (ed.), Democratic Civility, New Brunswick, N.J.: Transaction Books, 1998.

Ray A. Billington, The Protestant Crusade, 1800-1860: A Study of the Origins of American Nativism, New York: Macmillan, 1938; David Brion Davis, „Some Themes of Countersubversion: An Analysis of Anti-Masonic, Anti-Catholic, and Anti-Mormon Literature, "Mississipi Valley Historical Review 47, 1960; John Higham, Strangers in the Land: Patterns of American Nativism, 18601925, 2. ed., New Brusnwick, N.J.: Rutgers University Press, 1988; a "Instead of a Sequel, or, How i Lost My Subject,“" v Hirschman, Kasinitz, De Wind, Handbook of International Migration.

Herberg sám byl na základě teologického monoteizmu osobně velmi kritický vůči imanentnímu modlářskému charakteru amerického nebo jakéhokoliv jiného občanského náboženství.

Robert Bellah, „Civil Religion in America,“Daedalus 96, no. 1, 1967. 
skupiny, které byly již součástí staré imigrace. Ačkoliv jde o závažné opomenutí, lze stále ještě na jeho obranu uvést, že se tehdy jednalo o poměrně malé menšiny. Skutečným problémem ale je, že Herberg ignoruje skutečně významné rasové menšiny nacházející se mezi náboženskými skupinami, které zkoumá, a to konkrétně křest’anské ,jiné“: černé protestanty a hispánské katolíky. Herberg přece jen psal svoji studii v padesátých letech, na vrcholu velké vnitřní migrace černochů z agrárního Jihu na urbanizovaný Sever a migrace Portoričanů do New Yorku, pomineme-li jiné významné katolíky hispánského původu - „Chicanos“ z jihozápadu, kteří nebyli ve své většině, s výjimkou „Braceros“, přistěhovalci. ${ }^{27}$ Podobně jako v prŕpadě Portorika to byly hranice Spojených států, které se přistěhovaly na jejich původní území. Přesněji řečeno, je samozřejmé, že černoši a Hispánci nebyli přistěhovalí „,vetřelci“, je ale skutečností, že Herberg konstruuje ,protestanty“, „,katolíky“ a ,židy“ jako tři pomyslné náboženské komunity tvořící americký národ, což činí opomenutí „černochư“a „Hispáncư“ o to problematičtější a odhalující. Toto opomenutí černých protestantů a hispánských katolíků ukazuje, že v padesátých letech zůstávaly tyto skupiny neviditelnými rasovými „,vetřelci“, a to $\mathrm{v}$ době, kdy byli evropští přistěhovalci, katolíci a židé, začleňování do pomyslného společenství amerického národa.

Literatura zabývající se přistěhovalectvím oprávněně postavila otázky rasy, rasovosti a rasových identit do centra své analýzy procesů inkorporace přistěhovalců. Černoši a Hispánci se stali opravdovým tertium comparationis ve všech srovnávacích studiích staré a nové imigrace. Třemi srovnávanými tématy, minimálně implicitně, ve všech současných debatách jsou: a) bílí Evropané (staří přistěhovalci), b) americké rasové menšiny (černoši a Hispánci) a c) noví přistěhovalci z celého světa (z Asie, Karibiku, Latinské Ameriky, Afriky). Jakmile je srovnávací rámec nastaven tímto způsobem, stává se okamžitě zřejmým, že na rase záleží a že rasové záležitosti jsou v procesu inkorporace přistěhovalců klíčové. Herbergova studie ale ukazuje, že náboženství má také svůj význam a že náboženské otázky mohou být v procesu začleňování přistěhovalců v Americe stejně významné. Nikoliv samo náboženství, jak by se mohla snažit implikovat Herbergova studie, ani sama rasa, jak by se mohla snažit implikovat současná studia přistěhovalectví, ale náboženství a rasa a jejich komplexní propojení strukturující americkou zkušenost inkorporování přistěhovalců jsou skutečným klíčem $\mathrm{k}$,americké výjimečnosti““.28

27 Nicholas Lemann, The Promised Land. The Great Black Migration and How It Changed America, New York: Vintage, 1996; Nathan Glazer a Daniel Patrick Moynihan, Beyond the Melting Pot: The Negroes, Puerto Ricans, Jews, Italians and Irish of New York City, Cambridge, Mass.: MIT Press, 1963; Ana Maria Diaz-Stevens, Oxcart Catholicism on Fifth Avenue: the Impact of the Puerto Rican Migration upon the Archdiocese of New York, Notre Dame: University of Notre Dame Press, 1993; Jay P. Dolan a Jaime R. Vidal (eds.), Puerto Rican and Cuban Catholics in the United States 1900-65, Notre Dame, Ind: Notre Dame University Press, 1994; Jay P. Dolan a Gilberto M. Hinojosa, Mexican-Americans and the Catholic Church, 1900-65, Notre Dame, Ind.: University of Notre Dame Press, 1994.

Eric C. Lincoln, Race, Religion and the Continuing American Dilemma, New York: Hill \& Wang, 1984; Forrest G. Wood, The Arrogance of Faith: Christianity and Race in America from the Colonial Era to the Twentieth Century, New York: Alfred A. Knopf, 1990. Až donedávna nevěnoval obor imigračních studií náboženství žádnou pozornost, v uplynulém desetiletí se tato situace radikálně změnila. 
Při jisté míře zjednodušení lze prohlásit, že asimilace do amerického mainstreamu znamenala v první řadě přijetí identity WASP, nebo alespoň WASP podobné. Ze čtyř znamení americké identity - White, Anglo, Saxon, Protestant - byly těmi opravdu významnými první a poslední položky, rasa a náboženství. ${ }^{29}$ Mohli jste být tak bílí, jak jen to je možné, ale pokud jste nebyli protestanty, bylo jen velmi obtížné vás přijmout jako Američany. ${ }^{30}$ Irští protestanti (a nezapomínejme, že většina Američanů irského původu je z protestantského prostředí, jde o potomky skotských Irů) neměli nikdy problém s tím, aby byli přijímání jako bílí. Byli to naopak irští a jiní (italští, slovanští atd.) katolíci, kteří byli z rasového hlediska kategorizováni jako „ti druzí. Nicméně stát se tak zbožnými protestanty jako většina černochů také nestačilo. Pokud jste nebyli býlí, nemohli jste být plně američtí. ${ }^{31}$ Dnes se náboženství a rasa opět stávají dvěma základními znaky, které identifikují nové přistěhovalce bud' jako asimilovatelné, nebo jako podezřelé ,vetřelce“. ${ }^{32}$ Rasová a náboženská sebeidentifikace a vnější označení představují v tomto ohledu paralelní a občas alternativní způsoby organizování amerického multikulturalismu.

Spojené státy se opět staly přistěhovaleckou společností. Jen během uplynulého desetiletí přicházel do Spojených státu odhadem jeden milion přistěhovalců ročně, což představuje největší přistěhovaleckou vlnu v dějinách Spojených států, která překonává i oněch 9 milionů přistěhovalců, kteří přijeli v prvním desetiletí dvacátého století. Toto tempo se možná po 11. záŕí poněkud snížilo, ale neexistují nějaké jasné náznaky toho, že by se tento vývoj měl v blízké budoucnosti zastavit nebo zvrátit. Důležitější než růst počtu nových přistěhovalců jsou změny v jejich původu a charakteristice. Ve srovnání se starými přistěhovalci jsou dvěma hlavními rysy nových přistěhovalců to, že: a) jsou primárně ne-evropští, ze všech možných koutů světa, ale převážně z Asie a Latinské Ameriky, a b) ke své ohromné lidské rozmanitosti (rasové, etnické, náboženské, kulturní, jazykové), kterou si s sebou prrinášejí, jsou navíc také nesmírně rozdílní, téměř rozdvojení, co se týče úrovně jejich lidského a sociálního kapitálu, dovedností a zdrojů, které si s sebou přinášejí. ${ }^{33}$

29 Jazyk se stal problematickým znakem americké identity teprve nedávno, a to v souvislosti s protihispánskou mobilizací, která požaduje uzákonění angličtiny jako jediného ústavního oficiálního jazyka Spojených států. Pouze na jihozápadě, kde byl vždy významný rozdíl mezi „Anglos“ a "Hispanics“, byl jazyk významným znakem americké identity a dokonce i rasové kategorizace. Srov. Aristide R. Zolberg a Litt Woon Long, ,Why Islam is Like Spanish: Cultural Incorporation in Europe and the United States," Politics and Society 27, no. 1, 1999. Př́íladem prominentního představitele anglo-protestantského nativismu namířeného vůči hrozbě hispánských katolíků může být Samuel P. Huntington, Who Are We?: The Challenge's to America's National Identity, New York: Simon \& Schuster, 2004.

30 Noel Ignatiev, How the Irish Became White, New York: Routledge, 1995.

31 Desmond S. King, Making Americans: Immigration, Race, and the Origins of the Diverse Democracy, Cambridge, Mass.: Harvard University Press, 2000.

32 Bruce B. Lawrence, New Faiths, Old Fears: Muslims and Other Asian Immigrants in American Religious Life, New York: Columbia University Press, 2002.

33 Alejandro Portes a Rubén G. Rumbaut, Immigrant America: A Portrait, 2nd. ed., Berkeley: University of California Press, 1996. 
Z hlediska zájmu této studie je nejvýznamnějším rysem neobyčejný náboženský pluralismus a rozmanitost, jež přinášejí do země, která již tak byla tou nejvíce nábožensky pluralitní a nejrozmanitější zemí na světě. ${ }^{34}$ Jelikož americké vládní orgány nemohou shromažd'ovat informace o náboženském složení populace, nemáme spolehlivá data ani o náboženské př́íslušnosti nových přistěhovalců. ${ }^{35}$ Pokusy o odhady na základě náboženského složení zemí původu musejí zohledňovat skutečnost, že př́ílušníci náboženských menšin mají nadproporční sklon k imigraci do Ameriky. Arabští křest’ané a ruští židé v minulosti, korejští křest'ané a hispánští protestanti dnes jsou dobrými př́klady. Musíme si také být vědomi obtíži plynoucích z aplikace západních kategorií náboženské príslušnosti na ne-západní náboženství. Nominální př́islušnost je jako měřítko individuální zbožnosti v každém případě problematická, protože nám neříká nic o tom, jak moc nábožensky jsou tyto osoby ve skutečnosti založené, tedy zda, jak a jak často své náboženství praktikují. Kategorie, jakými jsou prŕslušnost k určité denominaci nebo „náboženské preference“, mohou objasnit náboženství „nepřidružených“ osob, zejména u těch náboženských praktik a forem náboženství, které nejsou definovány členstvím nebo př́slušností k organizované náboženské instituci, kongregaci nebo společenství.

V každém případě je bezpečnější předpokládat, že drtivá většina nových přistěhovalců jsou křest'ané, $v$ různém poměru katolíci a protestanti, společně s malým počtem pravoslavných, v závislosti na místě vstupu do USA. Pokud jde o New York, naše vlastní velmi hrubé odhady z projektu RIINY ukazují, že téměř 50 \% všech nových přistěhovalců jsou nominálně katolíci a přibližně $25 \%$ jsou nominálně protestanti. Protestanti a katolíci tak tvoří přibližně $75 \%$ všech nových prisstěhovalců do New Yorku. Je pravděpodobné, že pro Spojené státy jako celek bude celkový podíl křest’anů mezi novými přistěhovalci nižší - někde mezi dvěma třetinami a třemi čtvrtinami. ${ }^{36} \mathrm{Z}$ tohoto hlediska bude spočívat největší náboženský význam nových přistěhovalců $\mathrm{v}$ doplnění a obnově amerického křest’anství. Jelikož ale noví přistě-

Diana L. Eck, a New Religious America: How a „Christian Country “ Has Become the World's Most Religiously Diverse Nation, San Francisco: Harper, 2002.

New Immigrant Survey (NIS) má tuto situaci naštěstí zlepšit. Srov. http://nis.princeton.edu a poznámku 37, viz. níže.

New Immigrant Survey (NIS) má naštěstí za úkol zlepšení této situace. Podle New Immigrant Survey Pilot (NIS-P 1996) jsou o něco málo víc než dvě třetiny nových přistěhovalců nominálně „křest’ané“ (katolíci 41,9 \%; protestanti 18,6 \%; pravoslavní 4,2 \%), 2,6 \% se označilo jako židé, téměř $17 \%$ zvolilo ne-židovsko-křest’anská náboženství (muslimové $8 \%$; buddhisté $4 \%$; hinduisté $3,4 \%$; ostatní $1,4 \%$ ) a $15 \%$ zvolilo kategorii „bez vyznání“. Přesto musíme brát tato data s jistou opatrností vzhledem k velmi malému vzorku (976) respondentů. Vzorek dospělých osob v NIS2003, který bude zveřejněn n začátku roku 2006 a je mnohem větší (8573), a proto budou jeho data o „náboženských preferencích“ nebo nominální př́slušnosti nových přistěhovalců mnohem přesvědčivější. Srov. Guillermina Jasso, Douglas S. Massey, Mark R. Rosenzweig, a James P. Smith, „Exploring the Religious Preferences of Recent Immigrants to the United Sates: Evidence from the New Immigrant Survey Pilot,“ in Ivonne Yazbeck Haddad, Jane I. Smith a John L. Esposito (eds.), Religion and Immigration. Christian, Jewish, and Muslim Experiences in the United States, Walnut Creek, CA: AltaMira, 2003. S kategorií „,bez vyznání“ musíme ale také zacházet opatrně, protože může vyjadřovat spíše „žádnou konkrétní př́íslušnost k nějakému náboženství“ než „žádné náboženství“ - ve smyslu být zcela bez vyznání. To je např́íklad případ většiny čínských 
hovalci přinášejí ne-evropské verze křest’anství, přispějí také k de-evropeizaci amerického protestantismu a katolicismu. Hispanizace nebo latinskoamerikanizace amerického katolictví je zřejmým trendem. Ten je však doprovázen neméně významným trendem protestantizace Latinské Ameriky a Latinoameričanů. ${ }^{37}$

Nejpozoruhodnějším aktuálním trendem s možnými dalekosáhlými důsledky jak na státní, tak na globální úrovni, je vzrůstající počet prijijiždějících muslimů, hinduistů, buddhistů, vskutku zástupců všech regionů světa. Skutečné údaje nemusejí být tak vysoké jako přehnané odhady o 6-7 milionech muslimů, 2,8-4 milionech buddhistů a 1,2-2 milionech hinduistů, které se tu a tam objevují. Nicméně bitva o čísla a pokusy The National Opinion Research Center (NORC) a American Jewish Committee o zpochybnění těchto odhadů ve snaze dokázat, jak to hlásal titulek v Chicago Tribune, že „Křest’ané a židé stále převládaji“, míŕí nesprávným směrem. ${ }^{38}$

$\mathrm{Z}$ číselného hlediska nepředstavovali američtí židé nikdy reálnou výzvu křest’anské převaze, ale inkorporace judaismu jako amerického náboženství radikálně transformovala americkou náboženskou scénu a sebedefinování amerického národa. Je pravda, že na rozdíl od hluboce zakořeněného protestantského antikatolického nativismu se judaismus v Americe nikdy nesetkal s podobně silně zakořeněným antisemitismem a americký protestantismus obecně tíhl k filosemitskému postoji, ale přijetí katolicismu a judaismu jako amerických denominací změnilo samotný systém amerického denominalismu. Hrozba pocit’ovaná ze strany přistěhovaleckého katolicismu nebyla vyvolána primárně jeho rozsahem, ale skutečností, že na něj bylo pohlíženo jako na ne-americké náboženství - a to do té míry, do jaké byly „republikanismus“ a „ř́mskokatolictví“ definovány jako vzájemně neslučitelné věci.

Americký náboženský pluralismus expanduje a inkorporuje všechna světová náboženství stejným způsobem, jakým dříve inkorporoval náboženství starých přistěhovalců. ${ }^{39}$ Dochází zde ke spletitému procesu vzájemného vyrovnávání se. Podobně jako dřive katoli-

přistěhovalců, kteří jednoduše nemají žádný pojem pro náboženskou příslušnost v našem smyslu, a tak zvolí odpověd’ „bez vyznáni““, přestože se mohou pravidelně účastnit různých náboženských obřadů (taoisté, buddhisté, konfucianisté atd.). Největší část respondentů v NIS-P, kteří zvolili kategorii „bez vyznání“, byla skutečně z Číny $(63,5 \%)$ a Tchajwanu (40,6 \%). Velký počet respondentů u kategorie „bez vyznání“ ze zemí bývalého Sovětského svazu (37\%) bude pravděpodobně zahrnovat velký podíl etnických Židů, kteří čím budou v Americe déle, tím pravděpodobněji se denominují jako „židé“ bez ohledu na jejich současnou náboženskou praxi.

37 K hispanizaci amerického katolicismu a protestantismu a k paralelní protestantizaci Latinské Ameriky srov. Jay P. Dolan a Allan Figueroa Deck (ed.), Hispanic Catholic Culture in the United States, Notre Dame: University of Notre Dame Press, 1994; Ana Maria Diaz-Stevens a Anthony M. Stevens-Arroyo, Recognizing the Latino Resurgence in U.S. Religion, Boulder, CO.: Westview Press, 1998; Manuel A. Vasquez a Marie Friedmann Marquardt (eds.), Globalizing the Sacred: Religion Across the Americas, New Brunswick, N.J.: Rutgers University Press, 2003; David Martin, Tongues of Fire: The Explosion of Protestantism in Latin America, London: Blackwell, 1990; a Pentecostalism: The World Their Parish, London: Blackwell, 2002.

Chicago Tribune, Jan 29, 2002; T. W. Smith, Estimating the Muslim Population in the United States, New York: The American Jewish Committee, October 2001.

Srov. The Pluralism Project CD-Rom, On Common Ground: World Religions in America, New York: Columbia University Press, 1997. 
cismus a judaismus, dochází nyní $\mathrm{k}$,,amerikanizaci“ dalších světových náboženství jako jsou islám, buddhismus a hinduismus. V průběhu uvedeného procesu tato náboženství také transformují americké náboženství, zatímco náboženské diaspory v Americe slouží současně jako katalyzátory transformace těchto starých náboženství v jejich civilizačních domovech stejným zpo̊sobem, jakým americký katolicismus ovlivnil transformaci světového katolicismu a jakým americký judaismus transformoval judaismus světový. ${ }^{40}$

Dnes se opakuje podobný př́běh a jsou opakovány podobné modely konfliktní inkorporace. Je pravda, že modely inkorporace přistěhovalců se radikálně změnily díky expandujícímu multikulturalismu a rozšiřování globálních nadnárodních sítí. Rostoucí globální migrace vede naopak k většímu urychlení multikulturalismu a náboženského pluralismu, který nyní zahrnuje všechna světová náboženství. Americký experiment vstoupil do nové fáze. Spojené státy se nemají stát jen ,prvním novým národem“ vytvořeným především ze všech evropských národů. Tradiční model asimilace, která přetvářela evropské národy na americké ,etnikum“, již nemůže sloužit jako model inkorporace, když současná přistěhovalecká vlna pochází doslova z celého světa. Amerika je tak předurčena k tomu, aby se stala „první novou globální společností“ tvořenou všemi světovými náboženstvími a civilizacemi a to v době, kdy nábožensko-civilizační identity získávají stále větší význam na globální úrovni. $^{41}$

Kvůli zničující logice rasové kategorizace, tak nápadné a všudypřítomné v americké společnosti, získává v procesu inkorporace přistěhovalců dynamika formování náboženské identity dvojnásobně pozitivní formu. Vzhledem $\mathrm{k}$ institucionalizovanému přijetí náboženského pluralismu a náboženských identit (díky výše uvedeným strukturálním prríčinám) nepřekvapí, že se mezi přistěhovalci setkáme s vyšší mírou proklamace náboženských identit. Toto přihlašování se k náboženským identitám je navíc posilováno tím, co se zdá být obecnou obrannou reakcí většiny přistěhovaleckých skupin vůči z vnějšku připisovaným rasovým kategoriím, zejména pak vůči stigmatu rasové méněcennosti. Nové modely globální migrace činí naše absurdní binární rasové kategorie ještě více matoucí a neudržitelné. $V$ tomto kontextu vnáší zdůrazňování náboženských identit hinduisty z Indie a karibské oblasti, muslimy ze západní Afriky nebo kreolskými katolíky z Haiti do dynamiky rasové kategorizace dimenzi odporu z tohoto hlediska představují náboženská a rasová sebe-identifikace alternativní způsoby organizování amerického (a globálního) multikulturalismu. ${ }^{42}$ Jednou ze zjevných výhod nábo-

$40 \quad$ Jay P. Dolan, The American Catholic Experience, Garden City, N.Y.: Doubleday, 1985; Arthur Hertzberg, The Jews in America, Four Centuries of an Uneasy Encounter, New York: Simon \& Schuster, 1989; Laurence R. Moore, Religious Outsiders and the Making of Americans, New York: Oxford University Press, 1986; Haddad, Smith, Esposito, Immigration and Religion; Haddad, Esposito, Muslims on the Americanization Path?; Prema Kurien, ,Multiculturalism and Etnic Nationalism: The Development of an American Hinduism, “ Social Problems Vol 51, 3, 2004.

Stephen Protero (ed.), a Nation of Religions: The Politics of Pluralism in Multireligious America, Chapel Hill, N.C.: University of North Carolina Press, 2005. Tento trend samozřejmě zpochybňuje dvě Huntingtonovy teze současně: geopolitickou tezi o nevyhnutelném střetu civilizací a nostalgickou národní tezi o anglo-protestantské americké civilizaci, která zůstane nezměněna i přes inkorporaci všech přistěhovaleckých ,jiných“. 
ženského pluralismu oproti pluralismu rasovému je to, že je v rámci patřičné ustavní institucionalizace lépe slučitelný s principem rovnosti a ne-hierarchické rozmanitosti, a tím i se skutečným multikulturalismem.

Americký denominacionalismus funguje na třech rozdílných úrovních, z nichž každá ovlivňuje transformaci náboženství přistěhovalců v Americe odlišným způsobem. První je základní „kongregacionalistická“ úroveň místní náboženské komunity. Tato úroveň je nejdůležitější a odehrává se na ní základní proces amerikanizace. Jak správně poukázal Stephen Warner, mají všechna přistěhovalecká náboženství v Americe, bez ohledu na jejich institucionální formy $\mathrm{v}$ jejich tradičním civilizačním prostředí, sklon $\mathrm{k}$ přijetí typicky protestantské „kongregační“ formy. Přihodilo se to starým přistěhovalcům, katolíkům a židům, a děje se to i novým přistěhovalcům bez ohledu na to, zda již nějakou kvazi-kongregační formou disponovali, jako muslimové, nebo nemají žádnou kongregační tradici, jako buddhisté a hinduisté. Všechny náboženské komunity v Americe mají sklon k přijetí volné asociační formy a jsou inkorporovány jako neziskové organizace, které vedou laikové. Kostely, synagogy, chrámy, mešity atd. se stávají více než jen místem bohoslužeb nebo modliteb a ustavují se jako autentická centra komunity s různými vzdělávacími a sociálními službami, spolky a rekreačními aktivitami a centrem sítí s konkrétním posláním. Stávají se vskutku tím, co Tocqueville nazval školami demokracie a centry spolkového života přistěhovaleckých komunit.

Toto představuje zásadní rozdíl mezi americkými „denominacemi“ a evropskými „církvemi“, které se nikdy plně nepřetvořily v kongregační dobrovolná sdružení a zůstávají zakotveny v teritoriálně založených státních církvích a místních farnostech. Strukturální význam má skutečnost, že minimálně u některých skupin vyvolala americká zkušenost imigrace reflexivní potvrzení náboženských identit. Právě reflexivní potvrzení náboženské identity, tedy něco jako identifikování sebe sama a identifikace ostatními podle určité náboženské denominace, je zde klíčové. Tato aktivní, získaná a reflexivní denominace je navíc velmi odlišná od pasivní, připsané a nominální př́ślušnosti k náboženství, do kterého se člověk narodí. To byla samožrejmě i zkušenost katolických a židovských přistěhovalců v Americe. Nemohli jednoduše zachovat svoji nominální př́slušnost, přinejmenším ne tehdy, chtěli-li stejnou př́slušnost převést na svoje děti. Museli se stát dobrovolnými členy sdružení a aktivně udržovat a předávat své rodinné tradice.

Druhou úrovní je vlastní denominační úroveň ve významu, ve kterém původně vznikla jako doktrinálně, organizačně a etnicko-rasově pluralitní denominace v rámci amerického protestantismu. Zatímco hierarchicky organizovaná katolická církev byla schopna inkorporovat všechny katolické přistěhovalce (s výjimkou polské církve) do jednotné americké katolické církve prostřednictvím systému etnických farností, americký judaismus se také rozčlenil do tř́ hlavní proudů (reformního, konzervativního a ortodoxního). Není stále jasné, zda se různé větve nebo tradice jiných světových náboženství (islámu, hinduismu, buddhismu) v Americe institucionalizují jako oddělené denominace, nebo zda se objeví jiné denominační rozdělení.

42 Pronikavý př́iklad lze nalézt v Prema Kurien, „Being Young, Brown and Hindu: The Identity Struggles of Second Generation Indian Americans, “ Journal of Contemporary Ethnography (vyjde). 
A konečně třetí úrovní je národní úroveň ,pomyslného společenství“ ve smyslu, v němž Herberg hovoří o protestantech-katolících-židech jako o třech denominačních formách amerického občanského náboženství. Je to také úroveň, na které se náboženstvím přistěhovalců dostává symbolického uznání a tato jsou tak inkorporována do národa jako „americkác, bez ohledu na to, zda si vytvořila jednotnou národní organizaci.

Islám představuje ze všech nových přistěhovaleckých náboženství nejzajímavější zkušební případ a výzvu modelům inkorporace přistěhovalců ze tří vzájemně propojených důvodů:

1) z geopolitických důvodů a kvůli obecnému zobrazování islámu jako fundamentalistického náboženství je dnes islám, podobně jako dříve katolicismus, představován jako ,to cizí“, a proto „ne-americké“. Naneštěstí nabyly tyto debaty po teroristických útocích muslimských militantů z 11. září a vojenské reakci Spojených států na intenzitě. Je ale paradoxní, že tento vývoj povzbudil nejen debaty o domnělém střetu civilizací mezi islámem a Západem, ale také přinesl poznání, že islám již v Americe zapustil kořeny a stává se důležitým americkým náboženstvím. ${ }^{43}$

Můžeme nalézt zarážející podobnosti mezi dnešním diskurzem o islámu jako fundamentalistickém protimoderním náboženství neslučitelném s demokracií a dřívějším diskurzem o katolicismu. Od třicátých do padesátých let 19. století byl protikatolický protestantský nativismus založen na domnělé neslučitelnosti „,republikanismu“ a ,ř́mskokatolictví“. Ve svém popisu katolíků v Americe se tuto představu snažil odmítnout již Tocqueville, podobně jako vystupoval proti široce rozšířenému přesvědčení, sdílenému jak francouzskými republikánskými laicisty, tak francouzskými monarchisty-katolíky, že katolicismus je neslučitelný s moderní demokracií a svobodami jednotlivce.

Stejně jako dříve v případě katolicismu, odehrávají se uvnitř i vně islámu debaty o slučitelnosti tohoto náboženství, demokracie a moderních individuálních svobod na třech oddělených, ale přesto vzájemně propojených úrovních: a) v debatách ohledně správné artikulace muslimské ummy v prostředí diaspory nacházející se mimo Dar al Islam; b) v debatách o demokratické legitimitě muslimských politických stran v Turecku a v dalších zemích, které mohou, podobně jako v dřívějších dobách jejich stejně podezřelé katolické protějšky, zavést nové formy muslimské demokracie, podobné demokracii křest’anské; a za c) v debatách o domnělém střetu civilizací mezi islámem a Západem na geopolitické úrovni, což je nápadně podobné dřívějším debatám o střetu mezi „republikanismem“ a ,římskokatolictvím“. V podmínkách globalizace se všechny tři otázky stávají ještě spletitější a propojenější. ${ }^{44}$

Lze si také všimnout dvojznačného a komplikovaného procesu veřejného symbolického uznání islámu za americké náboženství, který připomíná procesy inkorporace katolicismu a judaismu. Sebedefinující diskurz, který Ameriku změnil z „křest’anského“ na „židovsko-křest’anský“ národ, nabyl nedávno nové denominační označení „,abrahámovský“, jež symbolicky zahrnuje všechna tři monoteistická náboženství, která odvozují svůj původ od první smlouvy Boha s Abrahámem. Přítomnost muslimského imáma společně s protestantským pastorem, katolickým knězem a židovským rabínem na veřejných ceremoniích ve Washingtonu

43 Viz. John Esposito v připravované publikaci The New Religious Pluralism and Democracy .

44 Olivier Roy, Globalised Islam. The Search for a New Umma, London: Hurst \& Company, 2004. 
a také ve velkých městských centrech se stala běžnou. ${ }^{45}$ Současně lze ale zaznamenat protestantský nativistický odpor vůči islámu, který započal již před 11. záŕím a od té doby ještě zesílil. ${ }^{46}$ Nový antimuslimský evangelický diskurz má tři hlavní zdroje:

a) Militantní premileniální sionismus šířený mezi americkými evangelíky, kteří po pádu Sovětského svazu převedli roli, kterou měly v jejich apokalyptických vizích blížícího se Armagedonu hrát komunistické ,hordy“ ze severu a jejich arabští sekulární a nacionalističtí spojenci na Blízkém východě, na muslimské země jako nepřátele Izraele.

b) Misionářské soupeření mezi muslimy a křest’any (evangelíky a př́slušníky apoštolské církve) napříč subsaharskou Afrikou a v dalších částech světa, kde se odehrávají etnicko-náboženské konflikty mezi muslimy a křest’any, jež přispívají k frustraci evangelíků z toho, že v muslimských zemích nemohou otevřeně hlásat slovo boží.

c) Globální „válka proti terorismu“ po 11. září 2001, kterou, vzdor pečlivě vyjadřovanému oficiálnímu odmítání Bílého domu, neváhali prominentní evangeličtí vůdci jako Pat Robertson, Franklin Graham a Jerry Fallwell označit za „kř́žovou výpravu“ a za nevyhnutelný konflikt mezi ve své podstatě „,násilnickým“ islámem a křest’anským světem. ${ }^{47}$

Nejznepokojivějším vyjádřením rostoucího nativistického protestantského protimuslimského diskurzu je řada „blasfemických“ hanlivých pojednání (psaných často muslimy, kteří konvertovali ke křest’anství, a připomínajících staré protipapežské traktáty), jež lze nalézt v křest’anských knihkupectvích a jež urážejí proroka Mohameda jako nemravného hř́šníka a znevažují islám jako falešný monoteizmus a abrahámovské náboženství, mající pohanské kořeny v předislámském uctívání Ka’aby.

2) Výzva, před kterou dnes stojí islám v Americe, spočívá v tom, jak přetvořit různorodou skupinu přistěhovalců z jižní Asie, jež dnes tvoří nejrychleji rostoucí skupinu muslimských prristěhovalců, z arabských zemí a ze západní Afriky v jednotnou americkou muslimskou ummu. $Z$ tohoto hlediska není tento proces nepodobný procesu inkorporace různých národních katolických skupin do jednotné americké katolické církve. Dvě možnosti, o kterých se dnes v muslimských komunitách napříč Amerikou hovoří (často formulované jako model islámského národa vs. model průbojné a vlivné židovské menšiny) opakuje některé debaty vedené uvnitř amerického katolicismu v 19. století. Otázkou je, zda by měl být islám v Ame-

45 Mezi symbolické milníky procesu veřejného uznání lze zařadit tyto události: jmenování prvního oficiálního islámského duchovního v americké armádě, který byl uveden do funkce v roce 1993, v americkém námořnictvu pak v roce 1996; muslimský symbol byl poprvé zahrnut do elipsy Bílého domu v roce 1997; Pentagon pořádal první ramadánovou hostinu pro muslimy v roce 1998; v listopadu 2000 zahájil v první den ramadánu zákonodárný sbor v New Jersey své zasedání četbou z Koránu. Přítomnost muslimů na oficiálních ceremoniích a náboženských setkáních se stala ještě nápadnější po teroristických útocích z 11. září. Srov. Jane Smith, Islam in America, New York: Columbia University Press, 1999.

46 Richard Cimino, „Evangelical Discourse on Islam after 9/11,“ studie představená na výročním zasedání Association for the Sociology of Religion, Atlanta, August 15-17. Mimo tuto studii se následují část opírá o osobní konverzaci s Richardem Ciminem na New School for Social Research.

47 Sonja Barisic, „Pat Roberson Describes Islam as a Violent Religion That Wants to Dominate,“ Associated Press, February 22, 2002. 
rice konstruován jako segregovaná obranná subkultura chránící sama sebe před zhoubnou amerikanizací, nebo zda by se měl organizovat jako veřejná průbojná alternativa v rámci amerického soutěživého multikulturalismu. Hrozba amerikanizace islámu, kterou by tato možnost obsahovala, by byla vyrovnána př́ležitostí $\mathrm{k}$ islamizaci Ameriky, již mnoho muslimů vnímá jako uskutečnění islámského univerzalizmu.

3) Vzhledem ke stále rostoucí islamizaci černošské komunity, procesu, který afroameričtí muslimové často popisují nikoliv jako konverzi, ale jako návrat k předotrockému africkému islámu, bude mít (často konfliktní) dialog a dynamická interakce mezi Afroameričany a muslimskými přistěhovalci dramatický dopad na transformaci americké kultury. Stále otevřenou zůstává otázka, který druh vnitřní struktury islám v Americe přijme: zda podlehne tomu, co H. Richard Niebuhr nazval „zlem denominacionalismu“, jej spatřoval v socio-ekonomickém a etnicko-rasovém rozdělení společnosti, nebo zda se bude organizovat do podoby národní (ve smyslu celoamerické) církve podobné ummě a bude schopen překonat své vnitřní etnicko-náboženské a právně-doktrinální rozdělení. Americký protestantismus, katolicismus a judaismus představují v tomto ohledu alternativní denominační modely. Americký islám si pravděpodobně vyvine svůj vlastní odlišný denominační model, který bude sdílet určité rysy se všemi třemi uvedenými denominacemi. Pokud však bude schopen překonat nějakým způsobem model kongregační rasové segregace, která sužuje americké křest’anství, a překoná rozpor mezi přistěhovaleckými muslimy a americkými černochy, bude to mít významný dopad na americké rasové vztahy.

Amerikanizace islámu je již v plném proudu i přes všechny obtíže představované debatami mezi jeho př́vrženci, nativistickým odporem a geopolitickými konflikty. Islám se nestává jen rychle rostoucím náboženstvím v Americe, ale také americkým náboženstvím, jednou $\mathrm{z}$ denominačních alternativ pro to, jak být z náboženského hlediska Američanem. Islám je navíc přeurčený $\mathrm{k}$ tomu, aby se (podobně jako katolicismus) stal významným veřejným náboženstvím, které bude $\mathrm{v}$ budoucnu pravděpodobně hrát významnou roli v amerických veřejných debatách.

Přeložil Petr Tomáš

\section{Literatura}

Asad, T. 2006. „Trying to Understand French Secularism.“ In H. de Vries (ed.) Political Theologies, New York: Fordham University Press.

Barisic, S. 2002. „Pat Roberson Describes Islam as a Violent Religion That Wants to Dominate." Associated Press, February 22.

Bauböck R. (ed.) 1994. From Aliens to Citizens: Redefining the Status of Immigrants in Europe. Aldershot: Ashgate.

Bauböck, R. 1991. Immigration and the Boundaries of Citizenship. Wien: Institut für Höhere Studien.

Bauböck, R.; Heller, A.; Zolberg, A. R. (eds.) 1996. The Challenges of Diversity: Integration and Pluralism in Societies of Immigration. Aldershot: Ashgate.

Bauböck, R.; Rundell, J. (eds.) 1998. Blurred Boundaries: Migration, Ethnicity, Citizenship. Aldershot: Ashgate.

Bellah, R. 1967. „Civil Religion in America.“ Daedalus 96, no. 1. 
Billington, R. A. 1938. The Protestant Crusade, 1800-1860: A Study of the Origins of American Nativism. New York: Macmillan.

Bowen, J. 2004. „Muslims and Citizens, France’s Headscarf Controversy.“ Boston Review, February/March.

Casanova, J. 1994. Public Religions in the Modern World. Chicago: University of Chicago Press.

Casanova, J. 1998. „Between Nation and Civil Society: Ethno-Linguistic and Religious Pluralism in Ukraine.“ In R. Heffner (ed.) Democratic Civility, New Brunswick, N.J.: Transaction Books.

Casanova, J. 2001. „Civil Society and Religion: Retrospective Reflections on Catholicism and Prospective Reflections on Islam." Social Research 68, 4 Winter.

Casanova, J. 2006. „Religion, Secular Identities and European Integration.“ In P. Katzenstein, T. Byrnes (eds.) Religion and European Integration, Cambridge: Cambridge University Press.

Cesari, J. 2004. L'Islam à l'Épreuve de l'Occident. Paris: La Découverte.

Cesari, J. 2004. When Islam and Democracy Meet: Muslims in Europe and in the United States. New York: Palgrave Macmillan.

Cimino, R. „Evangelical Discourse on Islam after 9/11.“ Studie představená na výročním zasedání Association for the Sociology of Religion, Atlanta, August 15-17.

Davie, G. 1994. Religion in Britain Since 1945: Believing Without Belonging. Oxford: Blackwell.

Davie, G. 2000. Religion in Modern Europe: A Memory Mutates, Oxford: Oxford University Press.

Davis, D. B. 1960. „Some Themes of Countersubversion: An Analysis of Anti-Masonic, Anti-Catholic, and Anti-Mormon Literature." Mississipi Valley Historical Review 47.

Diaz-Stevens, A. M. 1993. Oxcart Catholicism on Fifth Avenue: the Impact of the Puerto Rican Migration upon the Archdiocese of New York. Notre Dame: University of Notre Dame Press.

Diaz-Stevens, A. M.; Stevens-Arroyo, A. M. 1998. Recognizing the Latino Resurgence in U.S. Religion. Boulder, Co.: Westview Press.

Dolan, J. P. 1985. The American Catholic Experience, Garden City, N.Y.: Doubleday.

Dolan, J. P.; Deck, A. F. (eds.) 1994. Hispanic Catholic Culture in the United States. Notre Dame: University of Notre Dame Press.

Dolan, J. P.; Hinojosa, G. M. 1994. Mexican-Americans and the Catholic Church, 1900-65. Notre Dame, Ind.: University of Notre Dame Press.

Dolan, J. P.; Vidal, J. R. (eds.) 1994. Puerto Rican and Cuban Catholics in the United States 1900-65. Notre Dame, Ind: Notre Dame University Press.

Ebaugh, H. R.; Chafetz, J. S. (eds.) 2000. Religion and the New Immigrants, Walnut Creek, CA: AltaMira Press.

Eck, D. L. 2002. A New Religious America: How a „, Christian Country“ Has Become the World's Most Religiously Diverse Nation. San Francisco: Harper. On-line dokument, dostupný na: http://nis.princeton.edu

Fallaci, O. 2002. The Rage and the Pride. New York: Rizzoli. 
Ferrari, S; Bradney, A. (eds.) 2000. Islam and European Legal Systems. Aldershot: Ashgate. Gaspard, F; Khosrokhavar, F. 1995. Le Foulard et la République. Paris: La Découverte. Geisser, V. 2003. La Nouvelle Islamophobie. Parisl La Découverte.

Greeley, A. M. 1972. The Denominational Society; A Sociological Approach to Religion in America. Glenview, Ill.: Scott, Foresman.

Greeley, A. M. 2003. Religion in Europe at the End of the Second Millennium: A Sociological Profile. New Brunswick, N.J.: Transaction Books.

Hadaway, K.; Marler, P. L.; Chaves, M. 1993. „What the Polls Don’t Show: A Closer Look at U.S. Church Attendance.“ American Sociological Review, 58.

Haddad, Y. Y. (ed.) 2002. Muslims in the West: From Sojourners to Citizens. New York: Oxford University Press.

Haddad, Y. Y.; Esposito, J. L. (eds.) 1998. Muslims on the Americanization Path? Atlanta, Ga.: Scholars Press.

Haddad, Y. Y.; Smith, J. I. 202. Muslim Minorities in the West: Visible and Invisible. Walnut Creek, CA: AltaMira Press.

Haddad, Y. Y.; Smith, J. I.; Esposito, J. L. (eds.) 2003. Religion and Immigration. Christian, Jewish, and Muslim Experiences in the United States, Walnut Creek, CA: AltaMira.

Herberg, W. 1960. Protestant-Catholic-Jew. Garden City, N.Y.: Doubleday.

Hertzberg, A. 1989. The Jews in America, Four Centuries of an Uneasy Encounter. New York: Simon \& Schuster.

Hervieu-Leger, D. 2004. „Religion und Sozialer Zusammenhalt.“ Transit. Europäische Review, 26, Sommer.

Higham, J. 1999. „Instead of a Sequel, or, How I Lost My Subject.“ In Ch. Hirschman, P. Kasinitz, J. De Wind Handbook of International Migration: The American Experience, New York: Russell Sage.

Higham, J. 1988. Strangers in the Land: Patterns of American Nativism, 1860-1925, 2. vydání. New Brusnwick, N.J.: Rutgers University Press.

Hirschman, Ch.; Kasinitz, P.; de Wind, J. (eds.) 1999. The Handbook of International Migration: The American Experience. New York: Russell Sage.

Huntington, S. P. 2004. Who Are We?: The Challenge's to America's National Identity. New York: Simon \& Schuster.

Ignatiev, N. 1995. How the Irish Became White. New York: Routledge.

Jasso, G.; Massey, D. S.; Rosenzweig, M. R.; Smith, J. P. 2003. „Exploring the Religious Preferences of Recent Immigrants to the United Sates: Evidence from the New Immigrant Survey Pilot“" In Y. Y. Haddad, J. I. Smith, J. L. Esposito (eds.) Religion and Immigration. Christian, Jewish, and Muslim Experiences in the United States, Walnut Creek, CA: AltaMira.

Jelen, T.; Wilcox, C. (eds.) 2002. Religion and Politics in Comparative Perspective: The One, the Few and the Many. New York: Cambridge University Press.

King, D. S. 2000. Making Americans: Immigration, Race, and the Origins of the Diverse Democracy. Cambridge, Mass.: Harvard University Press.

Kurien, P. (vyjde). „Being Young, Brown and Hindu: The Identity Struggles of Second Generation Indian Americans.“ Journal of Contemporary Ethnography. 
Kurien, P. 2002. ,, We Are Better Hindus Here“ Religion and Ethnicity Among Indian Americans.“ In J. H. Kim a P. G. Min (eds.) Building Faith Communities: Asian Immigrants and Religions, Walnut Creek, CA: AltaMira Press.

Kurien, P. 2004. „Multiculturalism and Etnic Nationalism: The Development of an American Hinduism." Social Problems Vol 51, 3.

Kwon, H.-Y; Kim, K. Ch.; Warner, R. S. (eds.) 2001. Korean Americans and Their Religions. University Park, Pa.: Pennsylvania State University Press.

Lawrence, B. B. 2002. New Faiths, Old Fears: Muslims and Other Asian Immigrants in American Religious Life. New York: Columbia University Press.

Lemann, N. 1996. The Promised Land. The Great Black Migration and How It Changed America. New York: Vintage. Glazer, N.; Moynihan, D. P. 1963. Beyond the Melting Pot: The Negroes, Puerto Ricans, Jews, Italians and Irish of New York City. Cambridge, Mass.: MIT Press.

Leonard, K. I. 2003. Muslims in the United States: The State of Research. New York: Russell Sage.

Lincoln, E. C. 1984. Race, Religion and the Continuing American Dilemma. New York: Hill \& Wang.

Madeley, J.; Enyedi, Z. (eds.) 2003. Church and State in Contemporary Europe. London: Frank Cass.

Maréchal, B.; Allievi, S.; Dassetto, F.; Nielsen, J. (eds.) 2003. Muslims in the Enlarged Europe. Leiden: Brill.

Martin, D. 1978. A General Theory of Secularization. New York: Harper \& Row.

Martin, D. 1990. Tongues of Fire: The Explosion of Protestantism in Latin America. London: Blackwell.

Martin, D. 2002. Pentecostalism: The World Their Parish. London: Blackwell.

Mead, S. E. 1976. „Denominationalism: The Shape of Protestantism in America.“ In The Lively Experiment: The Shaping of Christianity in America, New York: Harper \& Row.

Modood, T. 2005. Multicultural Politics. Racism, Ethnicity, and Muslims in Britain. Minneapolis: University of Minnesota Press.

Modood, T.; Werbner, P. (eds.) 1997. The Politics of Multiculturalism in the New Europe: Racism, Identity, and Community. London: Zed Books.

Moch, L. P. 2003. Moving Europeans. Migration in Western Europe since 1650, 2. vydání. Bloomington: Indiana University Press.

Moore, L. R. 1986. Religious Outsiders and the Making of Americans. New York: Oxford University Press.

Portes, A.; Rumbaut, R. G. 1996. Immigrant America: A Portrait, 2 vydání. Berkeley: University of California Press.

Protero, S. (ed.) 2005. A Nation of Religions: The Politics of Pluralism in Multireligious America. Chapel Hill, N.C.: University of North Carolina Press.

Rath, J.; Penninx, R.; Groenendijk, K.; Meyer, A. 2001. Western Europe and Its Islam. The Social Reaction to the Institutionalization of ,New Religion 'in the Netherlands, Belgium and the United Kingdom. Leiden: Brill. 
RIINY: „Religion and Immigrant Incorporation in New York.“ Pod vedením J. Casanovy a A. Zolberga v rámci International Center for Migration, Ethnicity, and Citizenship na New School for Social Research, New York.

Roy, O. 2004. Globalised Islam. The Search for a New Umma. London: Hurst \& Company.

Said, B. 1997. A Fundamental Fear: Eurocentrism and the Emergence of Islamism. London: Zed Books.

Sciolino, E. 2004. „Debate Begins in France on Religion in the Schools.“ The New York Times, February 4.

Shadid, W. A. R.; Koningsveld, P. S. (eds.) 1996. Muslims in the Margin: Political Responses to the Presence of Islam in Western Europe. Kampen: Kok Pharos.

Shadid, W. A. R.; Koningsveld, P.S. (eds.) 1995 Religious Freedom and the Position of Islam in Western Europe. Kampen: Kok Pharos.

Smith, J. 1999. Islam in America. New York: Columbia University Press.

Smith, T. L. 1978. „Religion and Ethnicity in America.“ American Historical Review, 83.

Smith, T. W. 2001. Estimating the Muslim Population in the United States. New York: The American Jewish Committee.

The Pluralism Project CD-Rom. 1997. On Common Ground: World Religions in America, New York: Columbia University Press.

Trust, R. 1997. Islamophobia: A Challenge for Us All. London: Runnymede Trust.

Vasquez, M. A.; Marquardt, M. F. (eds.) 2003. Globalizing the Sacred: Religion Across the Americas, New Brunswick, N.J.: Rutgers University Press.

Vertovec, S; Peach, C. (eds.) 1997. Islam in Europe: The Politics of Religion and Community. Basingstoke: McMillan.

Warner, R. S.; Wittner, J. G. (eds.) 1998. Gatherings in Diaspora: Religious Communities and the New Immigration. Philadelphia: Temple University Press.

Weibel, N. 2000. Par Delà le Voile: Femmes d'Islam en Europe. Brussels: Complexe.

Williams, R. R. 1988. Religion of Immigrants from India and Pakistan: New Threads in the American Tapestry. New York: Cambridge University Press.

Wood, F. G. 1990. The Arrogance of Faith: Christianity and Race in America from the Colonial Era to the Twentieth Century. New York: Alfred A. Knopf.

Yang, F. 1999. Chinese Christians in America. University Park, Pa.: Pennsylvania State University Press.

Zolberg, A. R; Long, L. W. 1999. ,Why Islam is Like Spanish: Cultural Incorporation in Europe and the United States." Politics and Society, 27, no. 1.

\section{Autor}

José Casanova působí na New School for Social Research v New Yorku, v současné době jako profesor a vedoucí Katedry sociologie. Je autorem publikace Public Religions in the Modern World (1994, University of Chicago Press). Zabývá se tématy náboženství, demokratizace a sociální změny v zemích Latinské Ameriky a jižní a východní Evropy. V poslední době se jeho výzkumné aktivity soustředí převážně na proces budování ukrajinského státu a národa, a na průběh tržních reforem a občanské společnosti v této zemi. Kontakt: Casanova@newschool.edu 